\title{
La red social
}

Keywords: derecho; legislación; jurisprudencia; animal

La película, con el mismo título de mi editorial, acaba de estrenarse en nuestros cines. Fui a verla con curiosidad e interés el pasado fin de semana, no en vano Facebook es un fenómeno global, con millones de usuarios en todo el mundo. Un fenómeno que abarca a gentes de todas las edades, empresas, iniciativas culturales, sociales, artistas, académicos, políticos. Facebook es el equivalente -dicho sea sin pretensión de minimizar-, al paseo de los pueblos, donde se iba a ver y a ser visto. $Y$ a la vez es un negocio con unos ingresos, que han hecho de su creador el multimillonario más joven de la historia; nacido en mayo de 1984, tiene actualmente 26 años. Precisamente de la historia personal de Mark Zuckerberg, de cómo nació la idea de Facebook, trata la película, basada en el libro de Ben Mezrich, The Accidental Billionaires: the Founding of Facebook. A Tale of Sex, Money, Genius and Betrayal (2009).

La acción se sitúa en febrero de 2004 en el campus de la Universidad de Harvard; sin duda uno de los lugares por donde debería de pasar toda peregrinatio academica, para reforzar la propia formación, para abrirse a nuevas ideas, para respirar, a la vez, un clima de libertad, de disciplina y de trabajo: de esfuerzo honesto. No estoy idealizando lo que transmite la película, que también revela excesos, novatadas, desorden. Estoy refiriéndome a un clima de exigencia intelectual, donde mejorar y buscar la excelencia es la máxima que se transmite de generación en generación.

Las imágenes nos trasladan a edificios, a tradiciones, a códigos de conducta exigidos de forma natural por la comunidad universitaria y transgredidos, de forma igualmente natural. Estamos en los inicios de la búsqueda de una red virtual, que satisfaga la demanda de información sobre la vida de los otros, los compañeros con los que te cruzas en las aulas, en los bares, en la Bibliotecas. En ese ambiente, el guionista inserta, una escena reveladora del clima de Harvard y de las fuerzas sociales dominantes hace 6 años. Me refiero a las escenas en que a Eduardo Saverin, amigo de Mark Zuckerberg y cofundador de Facebook -nombrado pomposamente Director Comercial en los modestos inicios de la red-, se le acusa de maltrato animal. Sin revelar la trama, archiconocida -por lo demás- por el público, quiero detenerme en ese episodio que para nada aparece como tangencial en la historia. Al contrario, aparece como una acusación que está a punto de dar al traste con el progreso de la innovadora idea, que subyacía en Facebook desde sus comienzos.

En efecto, Eduardo Saverin sufre diversas pruebas para lograr su admisión en una de las fraternidades mas prestigiosas del campus. Una de tales pruebas de iniciación consiste en llevar consigo, a todas partes, a una gallina metida en una jaula, a la que, en un momento de tensión, le da de comer trozos del pollo que él mismo está tomando. Las Asociaciones de Estudiantes defensoras de los Derechos de los Animales en Harvard, cuando advierten tal conducta, le acusan formalmente ante las autoridades académicas de estar maltratando a la gallina, obligándola a ser caníbal. Se forma un escándalo de tal magnitud en el campus, una reacción tan contraria al maltrato animal, que el interesado, agobiado por la responsabilidad que se le avecina, afirma, según el guión: "En Harvard, es mejor ser acusado de robar que de maltratar a un animal”.

Sorprendente, ¿no es cierto?. ¿Podríamos imaginar una reacción semejante en febrero-marzo del 2004 durante el periodo de "novatadas” en cualquier campus español?. Me temo, que la respuesta es no. ¿Dónde está, pues, la diferencia?. ¿Existen en nuestras Universidades Asociaciones de Estudiantes que defiendan a los Animales, que tengan peso específico en la vida universitaria?. Me temo, que la respuesta es no. ¿ Produce el maltrato animal una reacción contraria, a nivel popular, tan importante como para 
preferir ser acusado de un delito de robo que de maltratar a una gallina?. Me temo que, de nuevo, la respuesta es no.

Para dar una explicación correcta al episodio de la gallina -que no de forma casual aparece en la película-, hay que tener en cuenta un dato importante. Harvard fue la primera Universidad de los Estados Unidos de América en donde se inició la enseñanza reglada de la asignatura de Derecho Animal (Animal Law) en 1999. El Profesor encargado de impartir aquellas clases en la prestigiosa Facultad de Derecho fue Steven Wise [1] , cuyo trabajo científico es mundialmente reconocido. Poco después se creó la Harvard Law School Animal Legal Defense Fund , con un gran influjo no sólo en el campus de Harvard sino en el resto de las Facultades de Derecho estadounidenses, en las que existen Asociaciones semejantes, que buscan "to develop state and federal strategic impact litigation and legislation to better the lives and legal status of animals”. Por lo tanto, existe en las Universidades americanas un compromiso no sólo personal, sino institucional en favor de la protección animal y de procurar, a través de los instrumentos jurídicos, “mejorar la vida y el estatuto jurídico de los Animales”.

La formación es la clave. Es importante lograr una sensibilización social en favor de los animales, pero la formación académica es decisiva para establecer bases sólidas, pensamiento crítico y capacidad de actuar de forma eficaz por la mejora de la protección animal. Por dicha razón, empezamos este año a impartir un Postgrado Universitario en “Animales-Derecho-Sociedad, pionero en nuestras Universidades, que dé la oportunidad de mejorar la formación de los que ya trabajan con, o a favor de los Animales y que procure una salida profesional a quienes se interesan por los Animales.

Por cierto, y para finalizar, nuestra web también tiene su lugar en Facebook (derechoanimal.info). Desde aquí os animo a estar al día de nuestras actividades a través de la "red social”. 